\title{
SOIL COVERAGE PLANTS PRECEEDING MAIZE CULTURE SUBMITTED TO DOSES OF NITROGEN FERTILIZATION
}

\author{
Douglas Martins Pereira Pellin ${ }^{1}$, Fábio Régis Souza 2 , Sadrac Borges Wendland ${ }^{3}$, Anderson \\ Cristian Bergamin ${ }^{2}$, Antonio Carlos Tadeu Vitorino ${ }^{4}$, João Augusto Araújo Colla ${ }^{3}$
}

\author{
${ }^{1}$ AGRAER-MS. Agronomic Engineer. E-mail: engpellin@ outlook.com \\ ${ }^{2}$ Federal University of Rondônia-Campus Rolim Moura. Professor Doctor. E-mail: fabio.souza@ unir.br; \\ andersonbergamin@hotmail.com \\ ${ }^{3}$ University Centre of the Grande Dourados Region. Agronomic Engineer. E-mail: sadracwendland@ @otmail.com; \\ joaoalbertocolla1@ hotmail.com \\ ${ }^{4}$ Federal University of Grande Dourados. Professor Doctor. E-mail: antoniovitorino@ufgd.edu.br
}

\begin{abstract}
This work aimed at evaluating the phytomass production and the accumulation of $\mathrm{N}$ in different soil coverage plants, as well as the effect of $\mathrm{N}$ doses applied in coverage on the maize cultivated in succession. The soil in the study area was classified as Dystroferric Red Latossoil with clayey texture. The experimental design used was the random blocks in factorial scheme of $5 \times 4$, with five coverage plants (millet, signalgrass, Crotalaria juncea, velvet bean, and fallow) anticipating the maize culture and four doses of mineral $\mathrm{N}\left(0 ; 67 ; 134\right.$; and $\left.201 \mathrm{~kg} \mathrm{ha}^{-1}\right)$, with three repetitions. The crotalaria was efficient in the production of accumulated-N, being able to be indicated as forerunner culture to maize. The decomposition rate of the coverages was more accelerated in the first 42 days after the drying, as well as the mineralization of $\mathrm{N}$. The maize culture reacted in na increasing way to the application of mineral-N.
\end{abstract}

Keywords: Zea mays, nitrogen, direct planting

\section{PLANTAS DE COBERTURA DO SOLO ANTECEDENDO A CULTURA DO MILHO SUBMETIDO A DOSES DE ADUBAÇÃO NITROGENADA}

\section{RESUMO}

Este trabalho teve como objetivo avaliar a produção de fitomassa e o acúmulo de $\mathrm{N}$ em diferentes plantas de cobertura de solo, bem como o efeito de doses de $\mathrm{N}$ aplicado em cobertura no milho cultivado em sucessão. O solo na área de estudo foi classificado como Latossolo Vermelho 
distroférrico de textura argilosa. O delineamento utilizado foi o de blocos casualizados em esquema fatorial $5 \times 4$, sendo cinco plantas de cobertura (milheto, braquiária, crotalária juncea, mucuna-preta e pousio) antecedendo a cultura do milho, e quatro doses de $\mathrm{N}$-mineral (0, 67, 134 e $\left.201 \mathrm{~kg} \mathrm{ha}^{-1}\right)$, com três repetições. A crotalária foi eficiente na produção de $\mathrm{N}$-acumulado, podendo ser indicado para cultura antecessora ao milho. A taxa de decomposição das coberturas foi mais acelerada nos primeiros 42 dias após a dessecação, assim como a mineralização de N. A cultura do milho respondeu de forma crescente às aplicações de N-mineral.

Palavras-chave: Zea mays; nitrogênio; plantio direto

\section{INTRODUCTION}

The traditional cultivation of maize, without the presence of dead coverage, increases the possibility of physical and chemical degradation of the soil, with consequences in the productivity of the culture, in the income, and in damages to the environment. With the adoption of the direct plantation system (SPD), the adequate soil coverage avoids the harmful action of the impact of raindrop, provides weed control, and increases the organic matter of the soil, besides contributing for the sustainable agricultural production (LIMA et al, 2015).

In the last years the climatic changes have caused delays in the rainfall distribution, slowing the sowing period of the main crops. This has compromised even more the production of phytomass obtained by the cultivation of winter crops or by the coverage plants. These coverage plants are normally species used with the objective of producing phytomass, with its wastes kept in the soil surface for the formation of dead coverage, increasing the efficiency of the direct planting system (ANDRIOLI \& PRADO, 2012).

The management of coverage plants, in surface or integrated with the soil, presents different decomposition rates (TORRES et al, 2005), with the relation $\mathrm{C}-\mathrm{N}$ being one of the main characteristics that interfere in the decomposition of vegetal wastes, due to the chemical nature of the product (MINGOTTE et al, 2012).

The quantity and quality of the haystack on the soil surface depends on the system of crop succession adopted mostly from the type of coverage and management (GOMES JUNIOR et al, 2008). Besides that, these species must favor a higher humidity retention in conditions of hydric 
deficit, spare nutrients to the cultures through the nutrient cycling (NUNES et al, 2006), and present inhibitory potential of unwanted plants (LIMA FILHO et al, 2014).

The nitrogen is the nutrient most extracted by the maize culture, and in the soil the nitrogen may suffer elevated losses by leaching and volatilization, implying an increase in the production cost. Therefore, there is a concern with the adequate management of this nutrient in the soil, leaving it available for the culture, decreasing losses, and increasing the efficiency of absorption by the plant (AITA \& GIACOMINI, 2003).

The decomposition of the vegetal wastes and the release of $\mathrm{N}$ for the maize may suffer interference with the addition of nitrogen fertilizers. When integrated, the release rate increases due to the accelerated decomposition of the wastes (BRAIDA et al, 2010).

Thus, knowing which soil coverage cultures predecessors to the maize cultivation can provide more $\mathrm{N}$ by the decomposition of its vegetal material is of great importance, aiming at the reduction of the mineral $\mathrm{N}$ doses applied to the maize plants, decreasing the production costs and the environmental impacts by the $\mathrm{N}$ contamination.

Considering this, the work had as objective evaluate the phytomass production, the decomposition, and the availability and accumulation of $\mathrm{N}$ in different soil coverage plants, as well as the effect of $\mathrm{N}$ doses applied in the maize coverage cultivated in in succession.

\section{MATERIAL AND METHODS}

The work was conducted at the experimental area of the University Centre of the Grande Dourados (UNIGRAN), located in the municipality of Dourados, state of Mato Grosso do Sul, Brazil. The region weather is the $\mathrm{C}_{\mathrm{wa}}$ type (humid mesothermal, hot summers and dry winters), with average rainfall of $1400 \mathrm{~mm}_{\text {year }}{ }^{-1}$, with the coldest month's temperature inferior to $18^{\circ} \mathrm{C}$ and the hottest month's temperature superior to $22^{\circ} \mathrm{C}$ (FIETZ \& FISCH, 2008). The soil of the experimental area was classified as Dystropherric Red Latossoil with clayey texture, according to the Embrapa's classification (2013).

The experimental design was the random blocks one, in a $5 \times 4$ factorial scheme with three repetitions; being five types of soil coverages and four doses of $\mathrm{N}\left(0,67,134\right.$, and $\left.201 \mathrm{~kg} \mathrm{~N} \mathrm{ha}^{-1}\right)$ in the form of urea, totaling 60 plots of $30 \mathrm{~m}^{2}$, covering an area of $1800 \mathrm{~m}^{2}$.

The experiment was conducted in September of 2009, with the implementation of the coverage soil types: millet (Pennisetum americanum sin. tiphoydes), signalgrass (Brachiaria 
ruziziensis), Crotalaria juncea (L.), velvet bean (Mucuna aterrima), and fallow (spontaneous vegetation) with predominance of the following species: Brachiaria decumbens, Panicum maximum Jacq., Digitaria horizontalis Willd., Brachiaria plantaginea (Link) Hitch., Setaria geniculata P. Beauy., Sida cordifolia (L.), Malvastrum coromandelianum (L.), Senna obtusifolia (L.), and Bidens pilosa (L.).

The desiccation of the coverage plants was carried at the 110 days after sowing. At the day before the desiccation of the coverage plants, there were collected samples of $0.5 \times 0.5 \mathrm{~m}$ of the aerial part randomly in order to determine the dry mass of the plants in each plot. For this the vegetal wastes were dried in incubator at $65^{\circ} \mathrm{C}$ until constant mass and the samples were forwarded to the determination of phytomass production and $\mathrm{N}$ rate by the distillation method of Kjehldal (HILDEBRAND, 1976). Subsequently, there was separated 40g of phytomass, based on the dry material mass, and put in litter bags of $20 \times 20 \mathrm{~cm}$ with mesh of $2 \times 2 \mathrm{~mm}$, which were distributed randomly in the soil's surface in each plot at the day of the maize sowing.

Next, the maize (hybrid DKB 390 YG) sowing was conducted using a fertilizing-sower of direct planting with four lines, aiming at a population of 65000 plants ha-1, with spacing of $90 \mathrm{~cm}$ between the lines, and 6 plants per linear meter.

The maize fertilizing was conducted in order to obtain a productivity of 6 to $8 \mathrm{mg} \mathrm{ha}^{-1}$. Each experimental unity contained four lines of maize with six meters of length, where the useful plot corresponded to $4 \mathrm{~m}$ of length of the two central lines of the experimental plot.

In the physiological maturation of the maize (R.1), there was made the removal of one litter bag, which was washed in flowing water using sieves for the removal of the adhered soil, and taken to the incubator at $65^{\circ} \mathrm{C}$ until constant weight in order to determine the dry mass. Meanwhile, the other litter bag remained at the plot until the maize harvesting day, being conducted the same process as previously cited. After the removal and drying of the litter bags there was conducted the analysis of tissue, accordingly to the Embrapa (1997), aiming at the verification of availability of nitrogen by the coverage plants.

The productivity of maize grains was obtained exceeding the grain production of the useful are of the plot to one hectare, considering the water rate of the seeds of $13 \%$.

In order to describe the decomposition of the vegetal wastes and the release of $\mathrm{N}$, it was applied an exponential mathematical model, described by Thomas \& Asakawa (1993) and used by Rezende et al, (1999): P = Po. Exp (-k.t), where (P) is the fraction of the initial waste in the time 
(t), (Po) is the proportion of the potentially decomposable waste, and (k) is the constant of decomposition of the waste. With the value of $(\mathrm{k})$, it was calculated the half-life time $\left(\mathrm{T}^{1 / 2}\right)$.

The soil samples were gathered in the depths of $0-10 \mathrm{~cm}$ using a Dutch auger. The determination of carbon of the BMS was conducted by the fumigation-extraction method (VANCE et al, 1987).

The data were submitted to the variance analysis and, when presented significance for the quantitative variables, there was used regression and for qualitative variables there was used mean test using Tukey at $5 \%$ of probability.

\section{RESULTS}

The yield of phytomass of the soil coverage species were significantly different ( $\mathrm{p}>0.05$ ). The crotalaria was the one which presented the highest production value among the used species, followed by the signalgrass and millet, with the fallow (spontaneous vegetation) and velvet bean being the ones which presented the lowest phytomass production values (Table 1). When comparing the fallow areas with those cultivated with crotalaria, the production was around 2.5 times higher and the signalgrass around 2 times, contributing with the conservation and protection of the soil besides the possible reduction of undesirable plants.

When the $\mathrm{N}$ rate (total) was compared, the velvet bean was the culture which produced the highest values for total $\mathrm{N}$ with $19.514 \mathrm{~g} \mathrm{~kg}^{-1}$, different from the crotalaria with $14 \mathrm{~g} \mathrm{~kg}^{-1}$ of $\mathrm{N}$ that, by its turn was superior to the species of grasses used, signalgrass, millet, and fallow (Table 1).

The productivity of the maize grains showed itself sensible to different coverages $(p>0.05)$. The management system with crotalaria and velvet bean presented the highest values of productivity of maize grains when compared to other species. The areas with grasses presented lower productivity values of maize grains when compared to the leguminous plants (Table 1).

The estimate of maximum grains productivity presented a quadratic answer to the application of mineral-N, with a maximum technical efficiency of $147,5 \mathrm{~kg} \mathrm{ha}^{-1}$ of mineral-N and a maximum agronomical efficiency of $10,9 \mathrm{~kg} \mathrm{ha}^{-1}$ of maize grains for each $\mathrm{kg}$ of mineral-N applied (Figure 2). 
Table 1. Phytomass production, total-N, accumulated-N and productivity of maize grains in function of different species of coverage used preceding the cultivation of maize at the Dourados-MS region.

\begin{tabular}{|c|c|c|c|c|}
\hline Vegetal & Total N & Phytomass & Accumulated N & Grains productivity \\
\hline Coverage $^{1}$ & $\mathrm{~g} \mathrm{~kg}^{-1}$ & ------------ & -------kg ha ${ }^{-1}$ & |----------------- \\
\hline Crotalaria & $14.0 \mathrm{~b}$ & $10905.7 \mathrm{a}$ & 152.1 & $10945 \mathrm{a}$ \\
\hline Velvet Bean & $19.5 \mathrm{a}$ & $3592.7 \mathrm{~d}$ & 70.1 & $10153 \mathrm{ab}$ \\
\hline Millet & $5.5 \mathrm{c}$ & $6503.4 \mathrm{bc}$ & 35.8 & $9338 \mathrm{bc}$ \\
\hline Signalgrass & $4.4 \mathrm{c}$ & $8534.0 \mathrm{~b}$ & 37.1 & $8458 \mathrm{~cd}$ \\
\hline Fallow & $7.9 \mathrm{c}$ & $4517.9 \mathrm{~cd}$ & 35.5 & $7830 \mathrm{~d}$ \\
\hline $\mathrm{CV}(\%)$ & 19.8 & 29.6 & & 10.38 \\
\hline
\end{tabular}

${ }^{1}$ Means followed by the same letter do not differ between each other by the Tukey Test at 5\%.

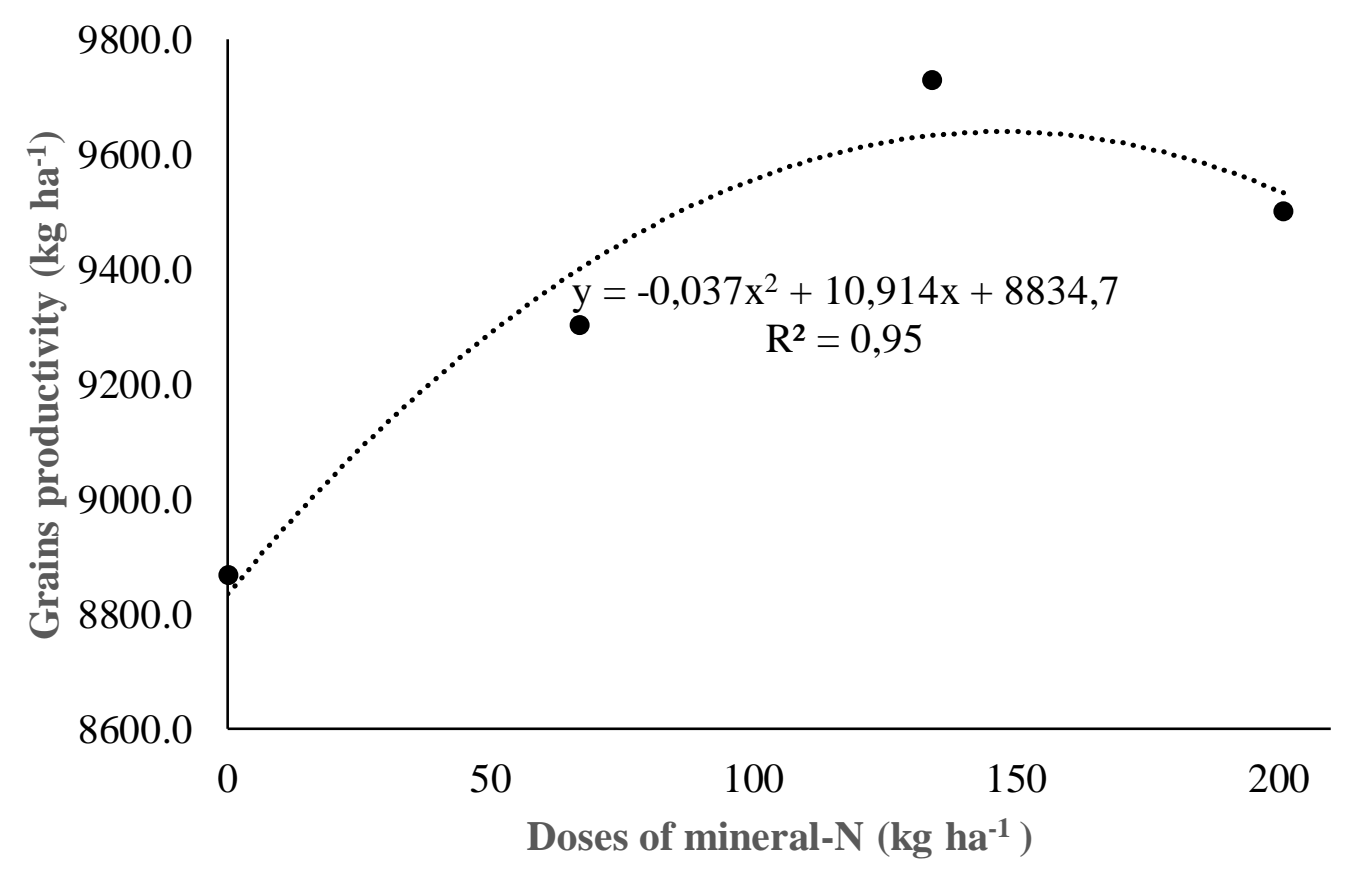

Figure 2. Mean data of productivity in function of doses of $\mathrm{N}$ in the fertilization of maize coverage of a Dystropherric Red Latosoil, at Dourados-MS region, July, 2010.

Table 2 presents the mean values of the outcome of interaction between the coverage species and doses of $\mathrm{N}$ for Carbon of Microbial Biomass (C-BMS). There were observed significant interactions between the doses of $\mathrm{N}$ applied and the type of coverage use in the 158 
accumulation of C-BMS. The system with native vegetation (VN), used as reference, presented a mean value of C-BMS of $1080.7 \mu \mathrm{g} \mathrm{C} \mathrm{g}$ dry soil ${ }^{-1}$, being significantly higher than the other treatments used.

In the cultivation of crotalaria, the mineral-N dose did not influence on the accumulation of C-BMS, presenting values similar to velvet bean. The species of grasses used as soil coverage (signalgrass and millet), presented elevated values of C-BMS when supplied with the most elevated doses of $\mathrm{N}$ (134 and $201 \mathrm{~kg} \mathrm{~N} \mathrm{ha}^{-1}$ ) (Table 2).

Table 2. Carbon of microbial biomass of the soil (Scale $=1 \mu \mathrm{g}$ ), determined in soils by the interaction between species of coverage and doses of mineral nitrogen, at the depth of 0-10cm, in a Dystropherric Red Latosoil, at Dourados-MS region, July, 2010.

\begin{tabular}{ccccc}
\hline Vegetal & \multicolumn{4}{c}{ Doses of mineral-N $\left(\mathrm{kg} \mathrm{ha}^{-1}\right)$} \\
\cline { 2 - 5 } Coverage $^{1}$ & 0 & 67 & 134 & 201 \\
\hline Crotalaria & $308.6235 \mathrm{aA}$ & $308.5800 \mathrm{aA}$ & $304.3815 \mathrm{aA}$ & $307.4867 \mathrm{aA}$ \\
Velvet Bean & $297.1938 \mathrm{abA}$ & $287.7920 \mathrm{abA}$ & $257.5150 \mathrm{aA}$ & $2623250 \mathrm{aA}$ \\
Millet & $204.5900 \mathrm{cB}$ & $206.8400 \mathrm{cB}$ & $285.0000 \mathrm{aA}$ & $295.3860 \mathrm{aA}$ \\
Signalgrass & $219.5359 \mathrm{cA}$ & $224.8183 \mathrm{bcA}$ & $270.7362 \mathrm{aA}$ & $275.9912 \mathrm{aA}$ \\
Fallow & $234.9267 \mathrm{bcA}$ & $251.5000 \mathrm{abcA}$ & $237.8700 \mathrm{aA}$ & $250.2182 \mathrm{aA}$ \\
\hline CV $(\%)$ & & 11.88 & & \\
\hline
\end{tabular}

${ }^{1}$ Highercase letters for comparing in lines and lowercase ones for comparing in columns. Means followed by the same letter do no differ between each other by the Tukey test at $5 \%$ of probability.

The kinetics of the process of decomposition of cultural wastes was similar in all of the coverages, decreasing with time. At the first 42 days, crotalaria, velvet bean and fallow were the ones which presented the highest decomposition rates, yet the grasses presented a slower decomposition (Figure 3), probably being related with the relation $\mathrm{C}: \mathrm{N}$ of these wastes.

For crotalaria, velvet bean and fallow, there were verified similar initial rates of decomposition; $45.6 \%, 45.6 \%$ and $43.7 \%$, respectively, in the first 42 days, while at 162 days the rates were $57 \%$ for leguminous plants and 54\% for fallow. For the Poaceae, signalgrass and millet, the rates were from 36 to $39 \%$, showing persistence wastes on the soil, and at 162 days the rates were from $44 \%$ to $47 \%$, showing an elevated halflife time $\left(\mathrm{T}^{1 / 2}\right)$ due to its $\mathrm{C}: \mathrm{N}$ relation (Table 3 ). 


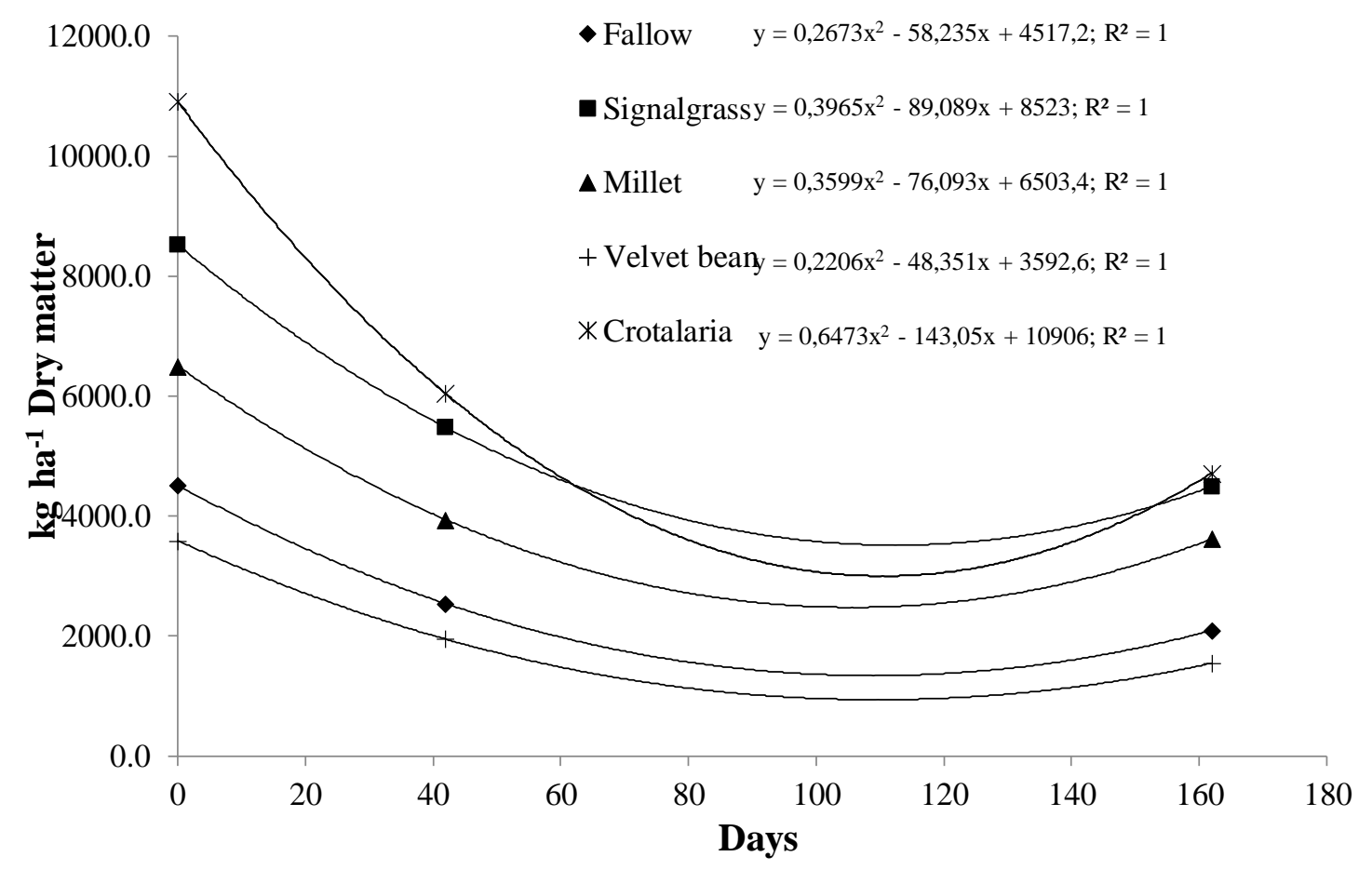

Figure 3. Mean decomposition data in function of the number of days (0, 42 and 162) after the plantation of coverage maize on the surface of a Dystropherric Red Latosoil, at Dourados-MS region, July 2010.

Table 3. Mean values of the decomposition of the coverages in function of the number of days $(0$, 42 and 162) after the plantation of the maize from the coverages on the surface of a Dystropherric Red Latosoil, Dourados-MS region.

\begin{tabular}{cccc}
\hline Vegetal Coverage $^{1}$ & 0 & 42 days & 162 days \\
\cline { 2 - 4 } & $----------------------k^{-1}$-------------------- \\
\hline Crotalaria & $10905.69 \mathrm{a}$ & $6039.45 \mathrm{a}$ & $4720.01 \mathrm{a}$ \\
Velvet Bean & $3592.64 \mathrm{~d}$ & $1951.10 \mathrm{c}$ & $1550.04 \mathrm{~b}$ \\
Millet & $6503.40 \mathrm{bc}$ & $4298.29 \mathrm{ab}$ & $3621.43 \mathrm{a}$ \\
Signalgrass & $8522.97 \mathrm{ab}$ & $5480.64 \mathrm{a}$ & $4495.93 \mathrm{a}$ \\
Fallow & $4517.17 \mathrm{~cd}$ & $2542.79 \mathrm{bc}$ & $2097.71 \mathrm{~b}$ \\
DMS & 2504.74 & 1803.98 & 1410.57 \\
CV $(\%)$ & 31.5 & 37.9 & 36.6 \\
\hline
\end{tabular}

${ }^{1}$ Means followed by the same letter in the column do not differ between each other by the Tukey test at 5\%. 
Table 4. Constant of decomposition and half-life time $\left(\mathrm{T}^{1 / 2}\right)$ of dry mass and mineral-N present on the coverages under different doses of mineral-N, at Dourados-MS region.

\begin{tabular}{|c|c|c|c|c|c|c|c|c|c|}
\hline \multirow{4}{*}{$\begin{array}{c}\text { Vegetal } \\
\text { Coverage }\end{array}$} & \multirow{3}{*}{ Doses of $\mathrm{N}$} & \multicolumn{4}{|c|}{ Wastes decomposition } & \multicolumn{4}{|c|}{$\mathrm{N}$ mineralization } \\
\hline & & \multicolumn{2}{|c|}{42 days } & \multicolumn{2}{|c|}{162 days } & \multicolumn{2}{|c|}{42 days } & \multicolumn{2}{|c|}{162 days } \\
\hline & & $\mathrm{k}$ & $\mathrm{T}^{1 / 2}$ & $\mathrm{k}$ & $\mathrm{T}^{1 / 2}$ & $\mathrm{k}$ & $\mathrm{T}^{1 / 2}$ & $\mathrm{k}$ & $\mathrm{T}^{1 / 2}$ \\
\hline & $\mathrm{kg} \mathrm{N} \mathrm{ha}^{-1}$ & $\mathrm{~g} \mathrm{~g}^{-1}$ & day & $\mathrm{g} \mathrm{g}^{-1}$ & day & $\mathrm{g} \mathrm{g}^{-1}$ & day & $\mathrm{g} \mathrm{g}^{-1}$ & Day \\
\hline \multirow{4}{*}{ Fallow } & 0 & 0.015 & 47 & 0.0052 & 142 & 0.013 & 61 & 0.004 & 202 \\
\hline & 67 & 0.012 & 60 & 0.0042 & 176 & 0.019 & 41 & 0.003 & 302 \\
\hline & 134 & 0.014 & 50 & 0.0048 & 147 & 0.014 & 92 & 0.003 & 305 \\
\hline & 201 & 0.015 & 49 & 0.0052 & 135 & 0.022 & 32 & 0.004 & 190 \\
\hline \multirow{4}{*}{ Signalgrass } & 0 & 0.012 & 61 & 0.0044 & 167 & 0.013 & 110 & 0.002 & 442 \\
\hline & 67 & 0.010 & 72 & 0.0038 & 186 & 0.015 & 48 & 0.005 & 179 \\
\hline & 134 & 0.009 & 75 & 0.0032 & 215 & 0.026 & 50 & 0.002 & 288 \\
\hline & 201 & 0.010 & 69 & 0.0040 & 173 & 0.022 & 42 & 0.007 & 120 \\
\hline \multirow{4}{*}{ Millet } & 0 & 0.011 & 71 & 0.0038 & 206 & 0.015 & 71 & 0.005 & 214 \\
\hline & 67 & 0.010 & 76 & 0.0035 & 215 & 0.012 & 89 & 0.004 & 160 \\
\hline & 134 & 0.007 & 104 & 0.0042 & 166 & 0.009 & 122 & 0.002 & 293 \\
\hline & 201 & 0.011 & 71 & 0.0033 & 237 & 0.008 & 92 & 0.003 & 297 \\
\hline \multirow{4}{*}{$\begin{array}{l}\text { Velvet } \\
\text { Bean }\end{array}$} & 0 & 0.017 & 40 & 0.0054 & 134 & 0.021 & 35 & 0.006 & 113 \\
\hline & 67 & 0.014 & 52 & 0.0045 & 157 & 0.019 & 46 & 0.004 & 157 \\
\hline & 134 & 0.014 & 53 & 0.0053 & 138 & 0.027 & 27 & 0.007 & 118 \\
\hline & 201 & 0.014 & 51 & 0.0057 & 121 & 0.023 & 31 & 0.007 & 102 \\
\hline \multirow{4}{*}{ Crotalaria } & 0 & 0.013 & 53 & 0.0046 & 155 & 0.030 & 27 & 0.007 & 117 \\
\hline & 67 & 0.014 & 61 & 0.0053 & 132 & 0.042 & 21 & 0.009 & 86 \\
\hline & 134 & 0.015 & 48 & 0.0053 & 133 & 0.028 & 28 & 0.010 & 70 \\
\hline & 201 & 0.015 & 50 & 0.0055 & 128 & 0.036 & 20 & 0.007 & 101 \\
\hline
\end{tabular}

$\mathrm{k}=$ Constant of decomposition; $\mathrm{T}^{1 / 2}=$ Half-life time

The quantity of $\mathrm{N}$ emitted also showed itself more expressive in the first 42 days for all coverages (Table 4), but crotalaria and velvet bean, due to its $\mathrm{N}$ fixation capacity, obtained the highest emissions during this period; $75 \%$ and $60 \%$, respectively. This states that under a condition where occurs accumulation of waste with a high $\mathrm{C}: \mathrm{N}$ relation, there are more chances of reduction of the $\mathrm{N}$ availability.

There was variability of $\mathrm{T}^{1 / 2}$ of the mineral-N (Table 4). Crotalaria reached a half-life time at 42 days and velvet bean did in approximately 35 days. For grasses, this time reached 110 days, for signalgrass 442 days and for millet 122 days. Regarding the coverages, even with the low $\mathrm{N}$-emission rate, these are the ones that more protect the soil due to its persistence on the surface. 


\section{SOIL COVERAGE PLANTS PRECEEDING MAIZE CULTURE SUBMITTED TO DOSES OF NITROGEN FERTILIZATION}

\section{DISCUSSION}

The production of phytomass is one of the most important requirements for the adoption of conservational practices, providing soil protection during the autumn-winter period, besides the diversification of cultures, avoiding a continuous succession of soybean/maize, one of the main characteristics of the agriculture from Cerrado region. In accord with Darol (1998), the minimum quantity of phytomass required for a rotation system is $6000 \mathrm{~kg} \mathrm{ha}^{-1}$ in a direct planting system, however the values obtained in this work were superior in the cultures of crotalaria, signalgrass and millet.

When the (total) $\mathrm{N}$ rate in the phytomass was compared, the velvet bean was the culture that produced the highest values, different from the crotalaria, being superior to the species of grass signalgrass, millet and fallow. This was expected because these are species that are capable of fixing the atmospheric $\mathrm{N}$ through symbiotic fixation (LIMA FILHO et al., 2014), besides the recycling of $\mathrm{N}$ from the soils in deeper layers. However, some works with green fertilizer, tagged with ${ }^{15} \mathrm{~N}$, indicate that after the decomposition, the biomass $\mathrm{N}$ of these plants have as destiny the soil (HARRIS \& HESTERMAN, 1990), therefore the cultivation with green fertilizer favors the development and productivity of the species in rotation or succession due to its waste effect (LIMA et al., 2015).

The different behavior between leguminous plants and grasses in the supply of $\mathrm{N}$ to maize can be explained by the leguminous plants capacity of fixing the atmospheric $\mathrm{N}_{2}$, by the differences in the $\mathrm{C}: \mathrm{N}$ relation and by the biochemical composition of these species (AITA et al., 2001).

The responses of maximum technical and economic efficiency can be estimated, provided that the other nutrients demanded by the culture are in great levels (SCHLINDWEIN \& GIANELLO, 2005). There is higher efficiency of use of $\mathrm{N}$ by the maize in condition of low nutrient supply, which aids to justify the elevated productivity observed in the treatment without fertilization of coverage (SOUZA et al., 2008).

The grasses presented a $\mathrm{C}: \mathrm{N}$ relation higher than the leguminous plants, above 30 (MENEZES \& LEANDRO, 2004), providing a slower decomposition; on the other hand, with the addition of mineral-N the decomposition of vegetal wastes is more accelerated. It is worth to highlight that more elevated values of microbial $\mathrm{C}$ implies in a higher temporary immobilization of nutrients and, consequently, in lower nutrient losses in the soil-plant system (MERCANTE et al., 2004, 2008). 
At 162 days after the desiccation, crotalaria, millet and signalgrass presented values superior to the ones obtained by Ferreira et al. (2010), with these coverage plants being a good alternative for the preceding cultivations.

The decomposition rate of the soil wastes did not suffer interference in the dose of $\mathrm{N}$ applied; possibly because the application of nitrogen fertilizer had occurred in sowing line of the maize and not in total area.

From 42 days the mineralization of $\mathrm{N}$ tended to become slower for all the coverages, showing that the rate of $\mathrm{N}$ mineralization occurs more rapidly until 42 days after the desiccation of the materials. With the elevated decomposition and $\mathrm{N}$ emission in the initial period, it is suggested that the implantation of the economic culture takes place as soon as possible (HEINZMANN, 1985).

The yield of maize grains responds to $\mathrm{N}$ depending on the type of vegetal coverage used and on the leguminous plants contributing with the variables $\mathrm{N}$ quantities for maize (GOMES JUNIOR et al., 2008; ROSOLEM et al., 2010). Silva et al. (2006) evaluated the efficiency of N use of crotalaria and millet, tagged with ${ }^{15} \mathrm{~N}$, by maize cultivated with different doses of $\mathrm{N}$, in direct planting; and observed that the maize cultivated in succession to millet, independently of the $\mathrm{N}$ dosage, the exploitation of $\mathrm{N}$ was inferior to the crotalaria $\mathrm{N}$, varying from 3.4 to $5.9 \%$ on the first, and from 7.2 to $11.9 \%$ in the second agricultural year, respectively. They also verified that a big part of the $\mathrm{N}$ of crotalaria and millet (36\%) absorbed by the maize was given back to the soil by the cultural wastes.

\section{CONCLUSIONS}

The preceding coverage culture significantly influences the productivity of the maize grains, being a good strategy for increasing the input of $\mathrm{N}$ on the soil.

Crotalaria accumulates $\mathrm{N}$ in its phytomass, being a possible indication as $\mathrm{N}$ provider culture when preceding maize culture.

The decomposition rate of the coverages was more accelerated in the first 42 days after the desiccation, as well as the mineralization of $\mathrm{N}$.

The maize culture responded to the applications of mineral-N in a crescent way. 


\section{REFERENCES}

AITA, C.; BASSO, C. J.; CERETTA, C. A.; GONÇALVES, C. N.; ROS, C. O. 2001 Plantas de cobertura de solo como fonte de nitrogênio ao milho, Revista Brasileira de Ciência do Solo, Viçosa, v. 25, n. 1, p.157-165.

AITA, C; GIACOMINI, S. J. 2003. Decomposição e liberação de nitrogênio de resíduos culturais de plantas de cobertura de solo solteiras e consorciadas, Revista Brasileira de Ciência do Solo, Viçosa, v. 27, n. 4, p. 601-612.

ANDRIOLI, I.; PRADO, R. M. 2012. Plantas de cobertura em pré-safra e adubação nitrogenada na fertilidade do solo em diferentes camadas, cultivado com milho em sistema de plantio direto e convencional, Semina: Ciências Agrárias, Londrina, v. 33, n. 3, p. 963-978.

BRAIDA, J. A.; REICHERT, J. M.; REINERT, D. J.; VEIGA, M. 2010. Teor de carbono orgânico e a susceptibilidade à compactação de um Nitossolo e Argissolo, Revista Brasileira de Engenharia Agrícola e Ambiental, Campina Grande, v. 14, n. 2, p. 131-139.

DAROLT, M. R. 1998. Princípios para implantação e manutenção do sistema. In: DAROLT, M. R. Plantio direto: pequena propriedade sustentável, Londrina: IAPAR, $1^{a}$ ed. p.16-45.

EMBRAPA. Centro Nacional de Pesquisa de solos. 2013. Sistema Brasileiro de Classificação de Solos, Rio de Janeiro: Embrapa Solos, $3^{\mathrm{a}}$ ed. 306p.

EMBRAPA. Centro Nacional de Pesquisa de Solos. 1997. Manual de métodos de análise de solo, Rio de Janeiro: Embrapa-CNPS, $2^{a}$ ed. 212p.

FERREIRA, E. P. B.; SANTOS, H. P.; COSTA, J. R.; DE-POLLI, H.; RUMJANEK, N. G. 2010. Microbial soil quality indicators under different crop rotations and tillage management, Revista Ciência Agronômica, Fortaleza, v. 41, n. 2, p. 177-183.

FIETZ, C. R.; FISCH, G. F. 2008. O clima na região de Dourados, MS, Dourados: Embrapa Agropecuária Oeste, $2^{\mathrm{a}}$ ed. 32p. (Documentos, 92).

GOMES JUNIOR, F. G.; SÁ, M. E.; VALÉRIO FILHO, W. V. 2008. Nitrogênio no feijoeiro em sistema plantio direto sobre gramíneas, Acta Scientiarum: Agronomy, Maringá, v. 30, n. 3, p. 387-395.

HARRIS, G. H.; HESTERMAN, O. B. 1990. Quantifying the nitrogen contribution from alfalfa to soil and two succeeding crops using nitrogen-15, Agronomy Journal, Madison, v. 82, n. 1, p. 129-134.

HEINZMANN, F. X. 1985. Resíduos culturais de inverno e assimilação de nitrogênio por culturas de inverno, Pesquisa Agropecuária Brasileira, Brasília, v. 20, n. 9, p. 1021-1030.

HILDEBRAND, C. 1976. Manual de métodos de análise químicas de solo e plantas, Curitiba: Universidade Federal do Paraná, $1^{a}$ ed. 225p.

LIMA FILHO, O. F.; AMBROSANO, E. J.; ROSSI, F.; CARLOS, J. A. D. 2014. Adubação verde e plantas de cobertura no Brasil: fundamentos e prática, Brasília: Embrapa, $1^{\circ}$ ed. $478 \mathrm{p}$.

LIMA, L. B.; PETTER, F. A.; LEANDRO, W. M. 2015. Desempenho de plantas de cobertura sob níveis de compactação em Latossolo Vermelho de Cerrado, Revista Brasileira de Engenharia Agrícola e Ambiental, Campina Grande, v. 19, n. 11, p. 1064-1071.

MENEZES, L. A. S; LEANDRO, W. M. 2004. Avaliação de espécies de coberturas do solo com potencial de uso em sistema de plantio direto, Pesquisa Agropecuária Tropical, Goiânia, v. 34, n.3, p. 173-180.

MERCANTE, F. M. M.; SILVA, R. F.; FRANCELINO, C. S. F.; CAVALHEIRO, J. C. T.; OTSUBO, A. A. 2008. Biomassa microbiana em um Argissolo Vermelho em diferentes 
coberturas vegetais em área cultivada com mandioca, Acta Scientiarum: Agronomy, Maringá, v. 30, n. 4, p. 479-485.

MINGOTTE, F. L. C.; YADA, M. M.; JARDIM, C. A.; LEMOS, L. B.; FORNASIERI FILHO, D. 2012. Análise econômica da adubação nitrogenada no feijoeiro em sucessão a milho e braquiária no plantio direto, Journal of Agronomic Sciences, Umuarama, v. 1, n. 1, p. 112119.

NUNES, U. R.; ANDRADE JÚNIOR, V. C.; SILVA, E. B.; SANTOS, N.; COSTA, H. A. O.; FERREIRA, C. A. 2006. Produção de palhada de plantas de cobertura e rendimento do feijão em plantio direto, Pesquisa Agropecuária Brasileira, Brasília, v. 41, n. 6, p. 943-978.

REZENDE, C. P.; CANTARUTTI, R. B.; BRAGA, J. M.; GOMIDE, J. A.; PEREIRA, J. M.; FERREIRA, E.; TARRE, R.; MACEDO, R.; ALVES, B. J. R.; URQUIAGA, S.; CADISCH, G.; GILLER, K. E. BODDEY, R. M. 1999. Litter deposition and disappearance in Brachiaria pastures in the Atlantic forest region of the South of Bahia, Brazil, Nutrient Cycling in Agroecosystems, Netherlands, v. 54, n. 2, p. 99-112.

ROSOLEM, C. A.; WERLE, R.; GARCIA, R. A. 2010. Nitrogen washing from $\mathrm{C}_{3}$ and $\mathrm{C}_{4}$ cover grasses residues by rain, Revista Brasileira de Ciência do Solo, Viçosa, v. 34, n. 6, p. 18991905.

SCHLINDWEIN, J. A.; GIANELLO, C. 2005. Doses de máxima eficiência econômica de fósforo e potássio para culturas cultivadas no sistema de plantio direto, Revista Plantio Direto, Passo Fundo, v. 85, n. 1, p. 20-25.

SILVA, E. C.; MURAOKA, T.; BUZETTI, S.; VELOSO, M. E. C.; TRIVELIN, P. C. O. 2006. Aproveitamento do nitrogênio $\left({ }^{15} \mathrm{~N}\right)$ da crotalária e do milheto pelo milho sob plantio direto em Latossolo Vermelho de Cerrado, Ciência Rural, Santa Maria, v. 36, n. 4, p. 739-746.

SOUZA, L. V.; MIRANDA, G. V.; GALVÃO, J. C. C.; ECKERT, F. R.; MANTOVANI, É. E.; LIMA, R. O.; GUIMARÃES, L. J. M. 2008. Genetic control of grain yield and nitrogen use efficiency in tropical maize, Pesquisa Agropecuária Brasileira, Brasília, v. 43, n. 11, p. 1517-1523.

THOMAS, R. J.; ASAKAWA, N. M. 1993. Decomposition of leaf litter from tropical forage grasses and legumes. Soil Biology \& Biochemistry, Oxford, v. 25, n. 10, p. 1351-1361.

TORRES, J. L. R.; PEREIRA, M. G.; ANDRIOLI, I.; POLIDORO, J. C.; FABIAN, A. J. 2005. Decomposição e liberação de nitrogênio de resíduos culturais de plantas de cobertura em um solo de Cerrado, Revista Brasileira de Ciência do Solo, Viçosa, v. 29, n. 4, p. 609-618.

VANCE, E. D.; BROOKES, P. C.; JENKINSON, D. S. 1987. An extraction method for measuring soil microbial biomass-C, Soil Biology \& Biochemistry, Oxford, v. 19, n. 6, p. 703-707.

Received in: October 20, 2016 Accepted in: July 15, 2019 